University of Nebraska - Lincoln

DigitalCommons@University of Nebraska - Lincoln

H. W. Manter Laboratory Library Materials

3-1919

On a Species of Hedruris Occurring Commonly in the Western

Newt, Notophthalmus torosus

Asa C. Chandler

Oregon Agricultural College

Follow this and additional works at: https://digitalcommons.unl.edu/manterlibrary

Part of the Parasitology Commons

Chandler, Asa C., "On a Species of Hedruris Occurring Commonly in the Western Newt, Notophthalmus torosus" (1919). H. W. Manter Laboratory Library Materials. 16.

https://digitalcommons.unl.edu/manterlibrary/16

This Article is brought to you for free and open access by DigitalCommons@University of Nebraska - Lincoln. It has been accepted for inclusion in H. W. Manter Laboratory Library Materials by an authorized administrator of DigitalCommons@University of Nebraska - Lincoln. 


\section{ON A SPECIES OF HEDRURIS OCCURRING COMMONLY IN THE WESTERN NEWT, NOTOPHTHALMUS TOROSUS *}

Asa C. Chandler

It has recently been pointed out by Ward and Magath (1916) that the nematode fauna of North American freshwater fishes is almost unknown. From a survey of the literature this state of affairs appears to be almost if not quite as true of the nematodes of other cold-blooded vertebrates in North America.

While making stomach examinations of the Western Newt or water-dog, Notophthalmus torosus, the writer found a large percent of specimens captured in the vicinity of Corvallis, Oregon, infested by a nematode which was evidently a species of Hedruris. The structure and ecology of this worm are so unique and proved so interesting and the references to it in the literature are either so slight or so difficult of access, that it seemed worth while to draw the attention of American helminthologists to it. Hitherto the members of the genus Hedruris have been looked upon as rare worms, and many helminthologists are no doubt unfamiliar with them.

According to Perrier (1871), whose account of Hedruris armata is by far the most thorough that can be found in literature of any species of Hedruris, these peculiar worms were first known to Rudolphi, but Perrier says: ". . . neanmoins leur caractéres si particuliers lui ont completement echappé, et il nous semble assez difficile de reconnaitre, comme le fait Schneider (Monogr. der Nemat., p. 107), l'Hedruris androphora dans l'Ascaris acuminata du savant helminthologiste." Nitzsch (1821) described the first known species, $H$. androphora, in a readily recognizable manner, and proposed its separation from the genus Ascaris into a new genus Hedruris. The first and only good description of $H$. androphora, the type species, is given by Schneider (1866). This species is found in various European amphibians and has been recorded from Bufo calamita, Bombinator igneus, Triton cristatus, Lissotriton punctatus and Proteus anguincus, always attached to the mucous membrane of the stomach.

Leidy (1851), apparently unaware of the existence of $H$. androphora, described a worm, evidently a Hedruris, which he found in the stomach and commencement of the small intestine of Clcmmys guttata, and named it Synplecta pendula. Baird (1858) very inadequately

\footnotetext{
* Contribution from the Zoological Laboratory, Oregon Agricultural College.
} 
described a Hedruris from the axolotl, "Siredon mexicanus"; the larval form of Ambystoma tigrinum, giving it the name Hedruris siredonis. Perrier (1871) described another species, $H$. armata, from the back part of the mouth cavity of Chrysemys picta. His description is, as already remarked, by far the most thorough of any which can be found in the literature. From the time of Perrier's paper to the present, no further research on this unique genus has been done, and very few references to it, even of the most casual kind, can be found.

The following is a diagnosis of the genus based on the descriptions of other authors and on the writer's observations on the species found in Notophthalmus torosus:

Cylindrical whitish worms, tapering from a fairly robust posterior end to a slender anterior end; surface of body more or less finely striated; mouth provided with two pairs of lips, a median and a lateral (Figs. 2 and 3 ); median lips (Fig. 2) thin, chitinized, concave on the upper surface, and attached to the worm only by the middle portion of the base; lateral lips (Fig. 3) enclosed by median ones, thick with elaborate chitinous skeleton, and united by a chitinous commissure: esophagus long, slender, muscular, crowned by a festooned chitinous ring and penetrating valve-like into the intestine, its lumen fourcornered, not three-cornered; intestine straight, cylindrical, terminating in a chitinous rectum in the female.

Female attaching itself to mucous membrane of host by means of posterior portion of body, which can be invaginated sucker-like and has attached to it a chitinized hook resembling the claw of a cat, the latter being used to hook into the mucous membrane of the host and to draw it up into the interior of the invaginated portion of the body (Fig. 5); female reproductive system double, with dilations of the oviducts which act as seminal vesicles (Fig. 7); vulva posterior, shortly anterior to the anus; eggs (Figs. 8 and 9) oval, provided with terminal opercula as in Trichuridae, and containing developed embryos when deposited.

Male smaller and slenderer than female, always rolled about his mate by about three spiral turns of the body; surface of body, anterior to anus, in contact with female on inner surface of spiral coil is provided with 15 to 20 rows of quadrangular tubercles, reminding one forcibly, both in appearance and function, of the elevations on certain kinds of non-skid tires (Fig. 6); spicules short, equal, crescent-shaped, with or without a small gubernaculum; one preanal and at least six postanal papillae.

Habitat of species so far known always stomach or back of mouth cavity of amphibians and pond turtles.

In many of the respects named above, Hedruris is absolutely unique among nematodes, and it is evidently a very highly specialized form. There can be no doubt, however, that it finds its nearest relatives among the Spiruroidea, and should be considered representative of an aberrant family belonging to this group as suggested by Railliet (1916). Perhaps the forms which approach nearest to it are the species of the genus Habronema (cf. figures by Ransom, 1913). The form and arrangement of the lips and the armature of the mouth; the chitinous crown for the esophagus (Figs. 2 and 3 ) and the general 
form of this organ; the form of the vagina, with a muscular mass surrounding its distal end (Fig. 5); the dorsal curvature of the tail of the female (Figs. 1 and 5); the chitinized rectum; the form, but not arrangement, of the male caudal papillae; are all strikingly similar to conditions found in Habronema. The cervical papillae of Habronema are also remarkably suggestive of the tactile spines described and figured by Perrier for Hedruris armata. Furthermore, the ventral surface of the body of the male of Habronema, anterior to the anus, is remarkably like that in Hedruris. Similar modifications occur in Arduenna and other spiruroids. On the other hand, Hedruris is less specialized than other spiruroids in the short, equal spicules, and more specialized in the development of the caudal adhering apparatus of the female, in the presence of distinct seminal vesicles, in the relation of the sexes, and also in the degree of specialization of the lips.

As already shown, four species of Hedruris have already been described, and considerable confusion exists as to the status and relationships of the species. In an endeavor to ascertain the identity of the species found by the writer in Notophthalmus torosus a careful comparison of the published descriptions of the species has been made and certain conclusions have been reached, though the incompleteness of the descriptions makes it necessary to assume more than is desirable.

The first described species, and therefore the type of the genus, is $H$. androphora Nitzsch. It may be defined as a small species, not exceeding $10 \mathrm{~mm}$. in length in the female and $8 \mathrm{~mm}$. in the male, within distinctly striated cuticula, and with mammillated eggs; it occurs as a stomach parasite of various European amphibians. The only other well-described species is that of Perrier, $H$. armata, which differs from $H$. androphora in its larger size ( \& $23 \mathrm{~mm}$., \& $20 \mathrm{~mm}$. long), in its distinctly striated cuticula in both sexes, in its non-mammillated eggs, and in the presence of tactile cervical spines; it occurs as a pharyngeal parasite of the American Chrysemys picta, having been obtained from a specimen in the menagerie of the Paris Museum of Natural History.

Perrier, when describing his species, was evidently unaware of the species described by Leidy twenty years before under the name $S_{y \prime n}$ plecta pendula. So far as Leidy's description goes, it appears to harmonize perfectly with that of Perrier. The size of Leidy's specimens (12.5 $\mathrm{mm}$. to $23 \mathrm{~mm}$. for the female and 8 to $10 \mathrm{~mm}$. for the male), the marked striation of the body, the number of caudal papillae of the male, and the lack of any mention of the eggs being mammillated on the sides, all ally this species with $H$. armata and not with $H$. androphora. Leidy does not mention cervical spines in his species, but one would hardly look for such a minute detail in such a superficial description. Leidy's specimens were taken from the stomach and commence- 
ment of the small intestine of Clemmys guttata, which, like Chrysemys picta, is a common pond turtle in Eastern United States. It appears very likely, therefore, that $H$. armata and $H$. pendula are synonyms, in which case the latter name would have to stand. Stiles and Hassall (1894) refer to specimens of Hedruris in Leidy's collection in the University of Pennsylvania taken from "Ambystoma mexicanum" and "Nanemys guttata" as $H$. androphora. Baird's $H$. siredonis is so meagerly described that its identity can only be inferred from circumstantial evidence. His description is based on a single female specimen, probably immature, taken from an axolotl from Mexico. The size, $13 \mathrm{~mm}$., and marked striation of the body, the only two characteristics of specific value mentioned, are evidence that it is not $H$. androphora. There is nothing except the host to distinguish it from $H$. armala or $H$. pendula, and it would naturally be included with them were it not for the fact that the specimens found by the writer in the western newt evidently represent a species distinct from either androphora or armata, and the probability is in favor of Baird's specimen being identical with the writer's species. So far as it goes, Baird's description agrees with the species found in Notophthalmus torosus, and its geographic occurrence and host both point to a probable identity of the two worms. Provisionally, therefore, the writer will refer to his specimens as $H$. siredonis Baird.

As found in Notophthalmus torosus, the last species appears to be more or less intermediate between $H$. androphora and $H$. armata. It is intermediate in size, the full grown females (Fig. 1) being $16 \mathrm{~mm}$. to $17 \mathrm{~mm}$. long, with a maximum width of from $0.5 \mathrm{~mm}$. to $0.6 \mathrm{~mm}$., while the males are $8 \mathrm{~mm}$. to $10 \mathrm{~mm}$. long by $0.23 \mathrm{~mm}$. wide. The body of the female is very coarsely striated; the striations are about $50 \mu$ apart, and each in turn is marked by from 12 to 15 exceedingly fine striations (Fig. 5). The body of the male, on the other hand, is very indistinctly striated, the striations being so light that when the body is curved they cannot be seen at all on the greater curvature. Male specimens cleared in carbolic acid show no evidence whatever of striation, whereas even the fine substriations of the female can be observed clearly. Often the striation of the male seems to be entirely missing, at least on parts of the body. This indistinctness of striation in the male is in contrast with the condition in $H$. armata, in which Perrier says the male is striated evenly from head to tail. There is no evidence whatever of cervical spines in $H$. siredonis. The male possesses a small gubernaculum in addition to the spicules, and has altogether ten pairs of postanal papillae, seven near the midventral line, two placed more laterally near the top of the tail, and one just behind the anus (Fig. 6). The eggs (Figs. 8 and 9) resemble those of 
H. androphora in their operculation, and also in the mammillated surface, a feature which is conspicuously absent from $H$. armata. The lips (Figs. 2 and 3 ), both median and lateral, are shaped a little differently in $H$. siredonis than in $H$, armata.

In other characteristics of structure and anatomy $H$. siredonis agrees with Perrier's description of $H$. armata (Fig. 7). The reproductive system is built on the same plan, but the ovaries with their radially arranged eggs are longer, and the seminal vesicles are more clistinctly marked off. The branches of the uterus also are larger and contain a greater number of eggs than is the case with $H$. armata, according to Perrier's figure. Hedruris is the only nematode known to the writer in which a completely distinct seminal vesicle is present. Hall describes a slight dilation of the anterior ends of the uteri of Dermatoxys z'eligera as a seminal vesicle; in this genus there is also a slender oviduct connecting ovary and uterus.

To sum up, the species of Hedruris may be characterized as follows:

1. Size small, $\&$ not exceeding $10 \mathrm{~mm}$. in length; indistinctly striated if at all; eggs mammillated; in stomach of European amphibians.

$H$. androphora Nitzsch.

2. Size medium, $\$ 16 \mathrm{~mm}$. to $17 \mathrm{~mm}$. long, distinctly striated; of indistinctly or not striated; eggs mammillated; in stomach of Notophthalmus forosus and axolotl. H. siredonis Baird.

3. Size large, i $23 \mathrm{~mm}$. long; both sexes distinctly striated; a pair of cervical tactile spines; eggs not mammillated; in pharynx of Chrysemys picta (probably identical with $H$. pendula Leidy from stomach of Clemmys guttata).

II. armala Perrier.

Unlike any previously described Hedruris, $H$. siredonis is an abundant parasite, at least in the vicinity of Corvallis. The majority of all specimens of Notophthalmus torosus examined are infested, frequently by a few worms, but sometimes by 20 to 25 pairs. Very often the females exceed the males in number, i. e., there are frequently females unaccompanied by males. Unattached males have never been found. Since it is always adult ripe females which are unaccompanied, it is to be presumed that the males die sooner than the females, and pass out of the digestive tract of the host. Nitzsch, however, states that he has found young females of $H$. androphora unaccompanied, assuming that they were too delicate to support the males.

That the worms when present in large numbers have an injurious effect on their hosts is evident. The nucous membrane of the stomach around the places where the worms adhere is often considerably swollen, and the point of attachment of the worms can sometimes be seen from the outer surface of the stomach. Perrier demonstrated 
that the caudal claw of the female worm is perforated and connected with a gland, thus imitating closely the fang of a solenoglyph snake, and, as suggested by Perrier, the probable function of the secretion of the gland is to irritate the tissues of the host sufficiently to cause a swelling, the latter making the attachment of the worm the more secure. On several occasions the writer has observed that heavily infested newts have been undersized and thin, and contain little or no food in the stomach.

$H$. sircdonis, as observed in life, is an extremely interesting animal. The invaginated posterior end of the female is seldom entirely everted, usually only far enough to throw the claw into such a position that it can seize a surface in contact with it and draw it back into the invagination. The worms are in general sluggish in movement, and appear to be incapable of the rapid swimming in which many nematodes indulge. The male worms, when slid off from the females, can only partially uncoil, and the permanent nature of the coils is demonstrated by the fact that when freed males are immersed in hot formalin the posterior end invariably coils in such a way as to leave a tube corresponding to the diameter of the female worm.

The life history of Hedruris is as yet unknown, outside of the fact, stated by Perrier, that the embryos escape from the eggs upon slight pressure, or sometimes spontaneously when in fresh water, probably due to osmosis. By analogy with other spiruroid worms, and from the fact that very small individuals are never found in the newts, it is probable that the eggs or embryos are swallowed by an intermediate host in which the early stages of development are passed, and that infection of the definitive host is brought about by feeding on the intermediate host.

\section{Literature Cited}

Baird, W. 1858.-Descriptions of Five New Species of Entozoa. Proc. Zool. London, pt. 26, 224-225, pl. 52.

Leidy, J. 1851.-Contributions to Helminthology. Proc. Acad. Nat. Sci., Phila., $5: 239-240$.

Nitzsch, C. L. 1821.-Ascaris, in Ersch and Gruber's Encyclopedia, 6:44-49. 2 pl.

Perrier, Ed. 1871.-Recherches sur l'organization d'un nematoide nouveau du genre Hcdruris. Nouv. arch. du mus. d'hist. nat. de Paris, 7:1-60, 2 pl. [Abstract of same under title "Sur l'organization d'un'espece nouvelle de nematoide appartenallt au genre Hedruris," Compt. rend. acad. des sci., Paris, 72 (12), 337-339.]

Railliet, A. 1916.-La Famille des Thelaziidae. J. Paras., 2:99-105.

Ransom B. H. 1913.-The Life History of Habronema muscae (Carter) a Parasite of the Horse Transmitted by the House Fly. U. S. Bur. An. Ind., Bull. 163,36 pp., 41 figs. 
Schneider. 1866.-Monographie der Nematoden. Rerlin, p. 107-108, pl. IV, fig. 8.

Stiles, C. W., and Hassall, A. 1894.-A Preliminary Catalogue of the Parasites Contained in the Collections of the U. S. Bur. An. Ind., U. S. Army Med. Mus., Biol. Dept. U. of Penn. (Coll. Leidy) and in Coll. Stiles and Coll. Hassall, Vet. Mag., 1:341.

Ward, H. B., and Magath, T. B. 1916.--Notes on some Nematodes from Freshwater Fishes. J. Paras., 3:57-64, 1 pl.

\section{Explanation of Plate}

Fig. 1.-Adult female Hedruris siridonis. $\times 11$.

Fig. 2.-Anterior end of body of $\delta$. siridonis showing median lip. Note chitinous commissure comecting lateral lips, and chitinous crown of oesophagus $\times 132$.

Fig. 3.-Anterior end of young $\%$, showing lateral lip. Note chitinous crown of esophagus; comparison of Figures 2 and 3 will show that the lumen of the oesophagus is four-cornered. Note also excretory pore and nerve ring. $\times 110$.

Fig. 4.- Male and female $H$. sircdonis in sitı. $\times 11$.

Fig. 5.-Posterior end of adult $\& H$. sircdonis, showing posterior portions of digestive and reproductive systems, and caudal adhering apparatus. $\times 28$.

Fig. 6.-Posterior end of \& $H$. sircdonis. Note longitudinal rows of quadrangular tubercles, the crescent-shaped spicules, the spearhead-like iulsernaculum, and ten pairs of post anal papillae.

Fig. 7.-Female reproductive system of $H_{i}$ druris mmala. Note arrinficment of eggs or ovaries and furm and position of seminal vesicles. After P'errier.

Figs. 8 and 9.-Eggs of $H$. sircdouis. $\times 260$.

$$
\text { Abpreviations Usen on Plate. }
$$

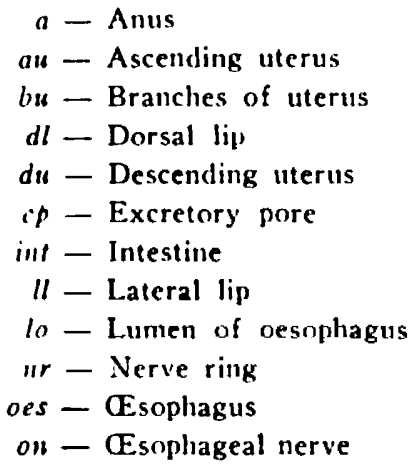

$$
\begin{aligned}
& m z \text { - Ovary } \\
& " i d \text { - Oviduct } \\
& p h \text { - Posterior hook } \\
& p s \text { - Posterior sucker } \\
& p s v \text { - Peduncle of seminal vesicle } \\
& s q \text { - Seminal vesicle } \\
& " \text { - Uterus } \\
& n p \text { - Uerus proper } \\
& i \prime \text { - Vagina } \\
& i n \text { - Vulva } \\
& \text { ao - Wall of oesophagus }
\end{aligned}
$$


CHANDLER-ON A SPECIES OF HEDRURIS

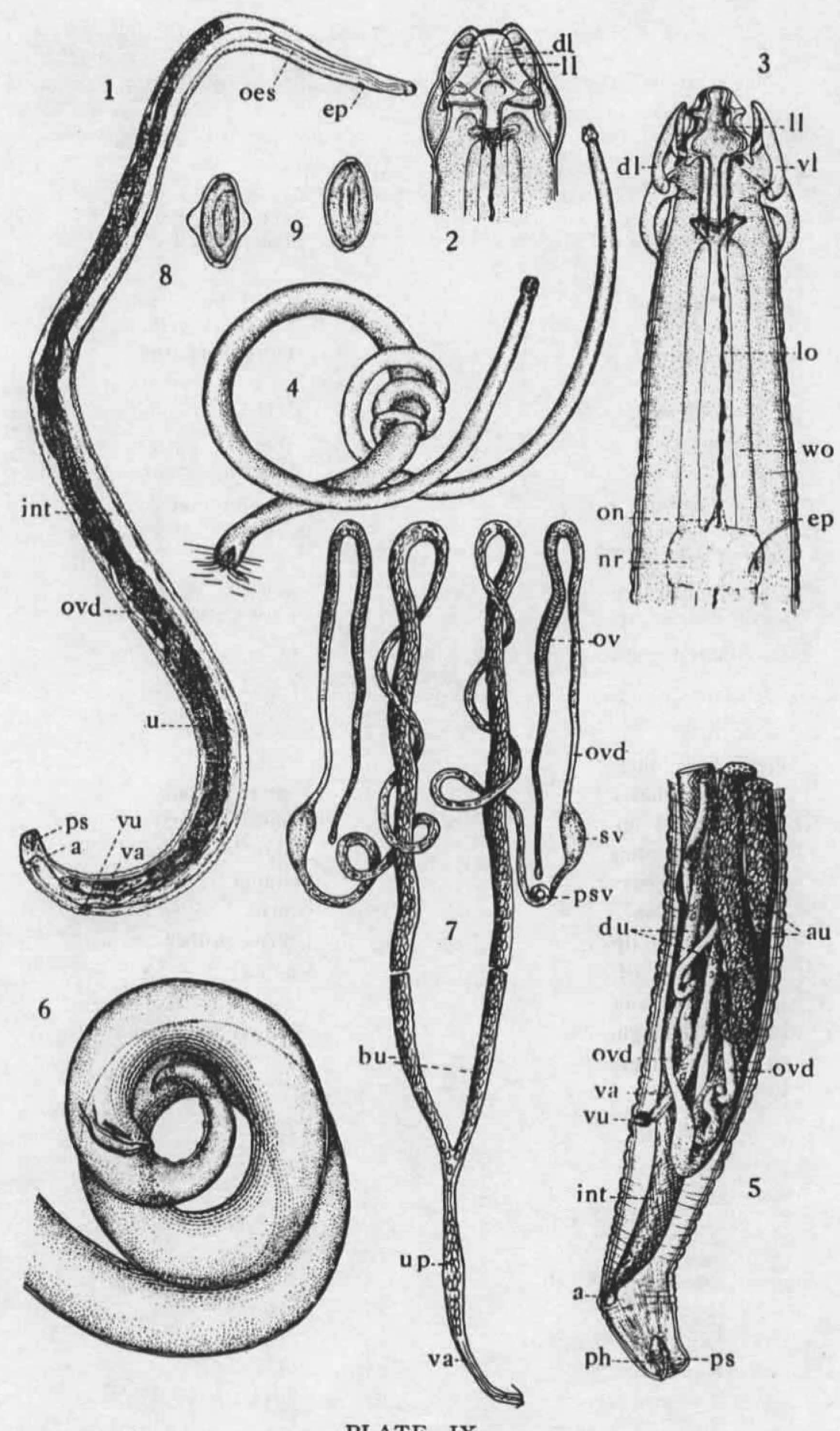

PLATE IX 